\title{
EDITORIAL
}

\section{Food from the sea}

One hundred and thirty five years ago, when the Marine Biological Association was founded at a meeting at the Royal Society in London, it was agreed to establish a laboratory at Plymouth with one of the key aims being to support the improvement in the effectiveness of fishing industry through the 'investigation of the habits and organisation of the fisheries of our British waters' (Anon 1887). Such endeavor in an international context is still of prime importance today. Our world population is projected to exceed 9 billion by 2050 and the gap in potential protein production for this world population increase has been emphasized (Godfray et al. 2010). Over recent decades this has led to increasing exploitation of food from the sea with the global production of fish increasing eight-fold since 1950 (Béné et al. 2015). Both fishing and aquaculture has contributed to this increased production. The effect of human diet on production of greenhouse gas emissions and consequent effects on climate change has been highlighted (Tilman and Clark 2014). Diets including fish rather than other animal proteins ameliorate such emissions and fish also has excellent nutritional qualities giving even further impetus to increasing fish production (Tilman and Clark 2014, Béné et al. 2015).

However, concerns have been expressed regarding the sustainability of fisheries in terms of serial overexploitation of fish stocks. Possible strategies for dealing with this require improved knowledge of individual stocks and the food webs of which they are part (Pauly et al. 2002). Such information is provided in this issue for the edible rock oyster (Saccostrea cucullata) (Singh 2019), the white shrimp (Litopenaeus schmitti) (Silva et al. 2019) and the Japanese jack mackeral (Trachurus japonicas) (Sassa et al. 2019). Arrighetti et al. (2019) give insights into the foodweb which supports the fisheries of a sub-tidal sandy ecosystem of the Mar del Plata off Argentina. A further aspect of maintaining production from the sea has been increasing utilisation of previously less desirable species (Pauly et al. 2002). Balogh et al. (2019) provide valuable information of the reproductive biology of the sea cucumber Stichopus herrmanni. This ecologically important holothurian, in common with other similar species, is increasingly being exploited for the trade in 'bêche-de-mer'.

Salmon farming is a well-researched and successful aquacultural enterprise. In this issue Kintner and Brierly (2019) document the effects on farmed fish of hydrozoan blooms on the north-west coast of Scotland, a previously unrecognised hazard to this longstanding industry. In contrast the abalone Haliotis tuberculata has traditionally been harvested from natural stocks. Recently, however, the species is being farmed. Key to effective management of farmed animals will be a thorough knowledge of their physiology. Chapperon et al. (2019) provide us with detailed information on respiration, calcification and excretion rates of this newly domesticated species.

Thus in keeping with one of the original aims of the Marine Biological Association the Journal welcomes and continues to publish papers pertaining to the topic of 'food from the sea' both in respect of fishing and aquaculture research.

\section{REFERENCES}

Anon (1887) The History of the Foundation of the Marine Biological Association of the United Kingdom. Journal of the Marine Biological Association of the United Kingdom 1, 17-21.

Arrighetti F., Teso V., Brey T. and Penchaszadeh P.E. (2019) Gastropod relevance in predator-prey interactions on a benthic shallow sandy ecosystem at Mar del Plata, Argentina $\left(38^{\circ} \mathrm{S}\right)$. Journal of the Marine Biological Association of the United Kingdom 99, 403-409.

Béné C., \& Barange M., Subasinghe R., Pinstrup-Andersen P., Merino G., Hemre G-I. and Williams M. (2015) Feeding 9 billion by 2050 Putting fish back on the menu. Food Security 7, 261-274.

Balogh R., Wolfe K. and Byrne M. (2019) Gonad development and spawning of the Vulnerable commercial sea cucumber, Stichopus herrmanni, in the southern Great Barrier Reef. Journal of the Marine Biological Association of the United Kingdom 99, 487-495.

Chapperon C., Clavier J., Dugué C., Amice E., Le Goff M. and Roussel S. (2019) Seasonal and diurnal variability in carbon respiration, calcification and excretion rates of the abalone Haliotis tuberculata L. Journal of the Marine Biological Association of the United Kingdom 99, 393-402.

Godfray H.C.J., Beddington J.R., Crute I.R., Haddad L., Lawrence D., Muir J.F., Pretty J., Robinson S., Thomas S.M. and Toulmin C. (2010) Food Security: The Challenge of Feeding 9 Billion People Science $327,812-818$.

Kintner A. and Brierley A.S. (2019) Cryptic hydrozoan blooms pose risks to gill health in farmed North Atlantic salmon (Salmo salar). Journal of the Marine Biological Association of the United Kingdom 99, 539-550.

Pauly D., Christensen V., Guénette S., Pitcher T.J., Sumaila U.R., Walters C.J., Watson R. and Zeller D. (2002) Towards sustainability in world fisheries. Nature 418, 689-695.

Sassa C., Kitajima S., Nishiuchi K. and Takahashi M. (2019) Ontogenetic and inter-annual variation in the diet of Japanese jack mackerel (Trachurus japonicus) juveniles in the East China Sea. 
Journal of the Marine Biological Association of the United Kingdom 99, 525-538.

Silva E.F., Calazans N., Nolé L., Soares R., Frédou F.L. and Peixoto S. (2019) Population dynamics of the white shrimp Litopenaeus schmitti (Burkenroad, 1936) on the southern coast of Pernambuco, northeastern Brazil. Journal of the Marine Biological Association of the United Kingdom 99, 429-435.

Singh Y.T. (2019) Biometrics, condition index and meat yield of edible rock oyster, Saccostrea cucullata (Born, 1778). Journal of the Marine Biological Association of the United Kingdom 99, 385-392. and

Tilman D. and Clark M. (2014) Global diets link environmental sustainability and human health. Nature 515, 518-522.

\section{Jane Lewis}

University of Westminster,

115 New Cavendish Street, London W1W 6UW email: lewisjm@westminster.ac.uk 